\title{
Pituitary gland metastasis from renal cell carcinoma presented as a non-functioning macroadenoma
}

\author{
Metástase de carcinoma de células renais para hipófise \\ simulando macroadenoma não funcionante
}

Caroline Kaercher Kramer', Nélson Ferreira², Sandra Pinho Silveiro', Jorge Luiz Gross', José Miguel Dora', Mirela Jobim de Azevedo'

\footnotetext{
1 Serviço de Endocrinologia, Hospital de Clínicas de Porto Alegre, Universidade Federal do Rio Grande do Sul (UFRGS), Porto Alegre, RS, Brazil ${ }^{2}$ Serviço de Neurocirurgia, Hospital São José, Complexo Hospitalar Santa Casa de Misericórdia de Porto Alegre, Porto Alegre, RS, Brazil
}

\section{SUMMARY}

Metastatic tumors involving the pituitary gland are an uncommon finding and occur in up to $1 \%$ of all pituitary tumor resections. A 74-year-old man had progressive vision deterioration, over the 30 days prior to consultation. He did not complain of headache or polyuria, but referred to intestinal constipation. Five years ago, he underwent a right radical nephrectomy for renal cell carcinoma, followed by chemotherapy and radiotherapy for lung and parotid metastases. On ophthalmologic examination, there was a left abducens nerve palsy and bitemporal hemianopia. Magnetic resonance imaging demonstrated a sellar mass with suprasellar cistern extension compressing the optic chiasm. Endocrinological evaluation revealed central adrenal and gonadal insufficiencies. The patient underwent a transsphenoidal tumor resection that revealed renal cell carcinoma. This case illustrates that metastatic pituitary lesions can mimic typical symptoms and signs of pituitary macroadenoma. Furthermore, clinical diabetes insipidus, a common finding of pituitary metastases, can be absent. Arq Bras Endocrinol Metab. 2010;54(5):498-501

\section{SUMÁRIO}

Correspondence to: Caroline Kaercher Kramer Serviço de Endocrinologia do Hospital de Clínicas de Porto Alegre Rua Ramiro Barcelos, 2350, Prédio $12,4^{\circ}$ andar 90035-003 - Porto Alegre, RS, Brazil

carolinekkramer@gmail.com

Metástases de neoplasias para hipófise são incomuns e ocorrem em até 1\% dos tumores de hipófise. Apresentamos o caso de um homem de 74 anos de idade com progressiva deterioração visual nos 30 dias que antecederam seu atendimento. Ele negava cefaleia ou poliúria e queixava-se de constipação intestinal. 0 paciente havia sido submetido à nefrectomia radical para carcinoma de células renais cinco anos antes, seguida de quimioterapia e radioterapia por metástases pulmonares e parotídea. Ao exame oftalmológico, apresentava paralisia do nervo abducente esquerdo e hemianopsia bitemporal. A ressonância magnética demonstrou uma massa selar com extensão suprasselar comprimindo o quiasma óptico. Na avaliação endocrinológica apresentava insuficiência adrenal e gonadal centrais. 0 paciente foi submetido à ressecção transesfenoidal da lesão que, ao exame anatomopatológico, se revelou como carcinoma de células renais. Esse caso demonstra que a presença de lesões metastáticas na hipófise pode mimetizar sinais e sintomas de macroadenoma não funcionante e que o diabetes insípido central, comum nas lesões metastáticas para hipófise, pode estar ausente. Arq Bras Endocrinol Metab. 2010;54(5):498-501

\section{INTRODUCTION}

$\mathrm{M}$ etastatic tumors involving the pituitary gland is an uncommon finding and occurs in up to $1 \%$ of all pituitary tumor resections ( 1 ) and in 0.14 to $28 \%$ of all brain metastases in autopsy series (2-3). We present a case of a renal cell carcinoma metastatic to the pituitary gland and a brief review of the literature.

\section{CASE REPORT}

A 74-year-old man presented with progressive visual deterioration over the 30 days prior his medical appointment. He did not complain of headaches or polyuria, and referred intestinal constipation. Five years before, he had undergone a right radical nephrectomy for renal cell carcinoma. Ten months after the surgery, chemothe- 
rapy for lung and parotid metastases were performed and 2 years later radiotherapy for lung metastases was conducted. A total thyroidectomy had been performed six years before, because of a multinodular compressive goiter and the patient has been using $100 \mu \mathrm{g} /$ day of levotiroxine since then. On physical examination heart rate was $84 \mathrm{bpm}$, blood pressure $120 / 70 \mathrm{mmHg}$, and $115 / 66 \mathrm{mmHg}$, respectively at recumbent and standing positions. His skin was pale and dry, and Achilles tendon reflexes were blunted. On ophthalmologic examination, there was a left abducens nerve palsy and bitemporal hemianopia. No abnormalities were observed on genitalia examination. Magnetic resonance imaging (MRI) demonstrated a $1.2 \times 0.9 \mathrm{~cm}$ sellar mass with suprasellar cistern extension compressing the optic chiasm. Precontrast Tl-weighted images showed intermediate homogeneous isointense signal and heterogeneous signal in T2-weighted images. After gadolinium infusion there was a heterogeneous enhancement, suggesting a highly vascular content (Figure 1). Endocrinological evaluation revealed pituitary insufficiency as follows: serum ACTH $<10 \mathrm{pg} / \mathrm{mL}$ [reference range (RR): 10-52] and cortisol values of $0.6,6.1$ and $3.9 \mu \mathrm{g} / \mathrm{dL}$ at 0,30 and 60 minutes after i.v. cortrosyn $1 \mu \mathrm{g}$; serum testosterone < $12 \mathrm{ng} / \mathrm{dL}$ (RR: 280-1100); FSH $2.5 \mathrm{ng} / \mathrm{dL}$ and LH < $0.7 \mathrm{ng} / \mathrm{dL}$. Prolactin values were slightly increased [ 32 $\mathrm{ng} / \mathrm{mL}$ (RR: 3-19)] and growth hormone axis [IGF-1 $150 \mathrm{ng} / \mathrm{mL}$ (RR: 79-290)] seemed to be unaffected. Free T4 was $0.8 \mathrm{ng} / \mathrm{dL}$ (RR: 0.7-1.9) and TSH was $0.14 \mu \mathrm{UI} / \mathrm{mL}$ (RR: 0.3-6.5). Serum sodium and potassium were $142 \mathrm{mEq} / \mathrm{L}$ and $4.5 \mathrm{mEq} / \mathrm{L}$, respectively. Hemoglobin was $11 \mathrm{~g} / \mathrm{dL}$. A visual threshold field test showed a progressive bitemporal hemianopia on serial evaluation 2 months apart, due to tumor compression. The patient underwent a transsphenoidal tumor resection due to progressive visual loss and the histological examination of the tumor revealed renal cell carcinoma with rich vascular content (Figure 2 ). The study protocol was approved by the ethics committee of the hospital, and consent was obtained from a relative of the patient.

\section{DISCUSSION}

This is the case report of a 74-year-old man with a previous nephrectomy for renal cell carcinoma who presented progressive visual loss and a $1.2 \mathrm{~cm}$ sellar mass compressing the optic chiasm in MRI. Central hypoadrenalism and hypogonadism were present, and surgical resection disclosed a renal cell carcinoma metastatic to the pituitary gland.
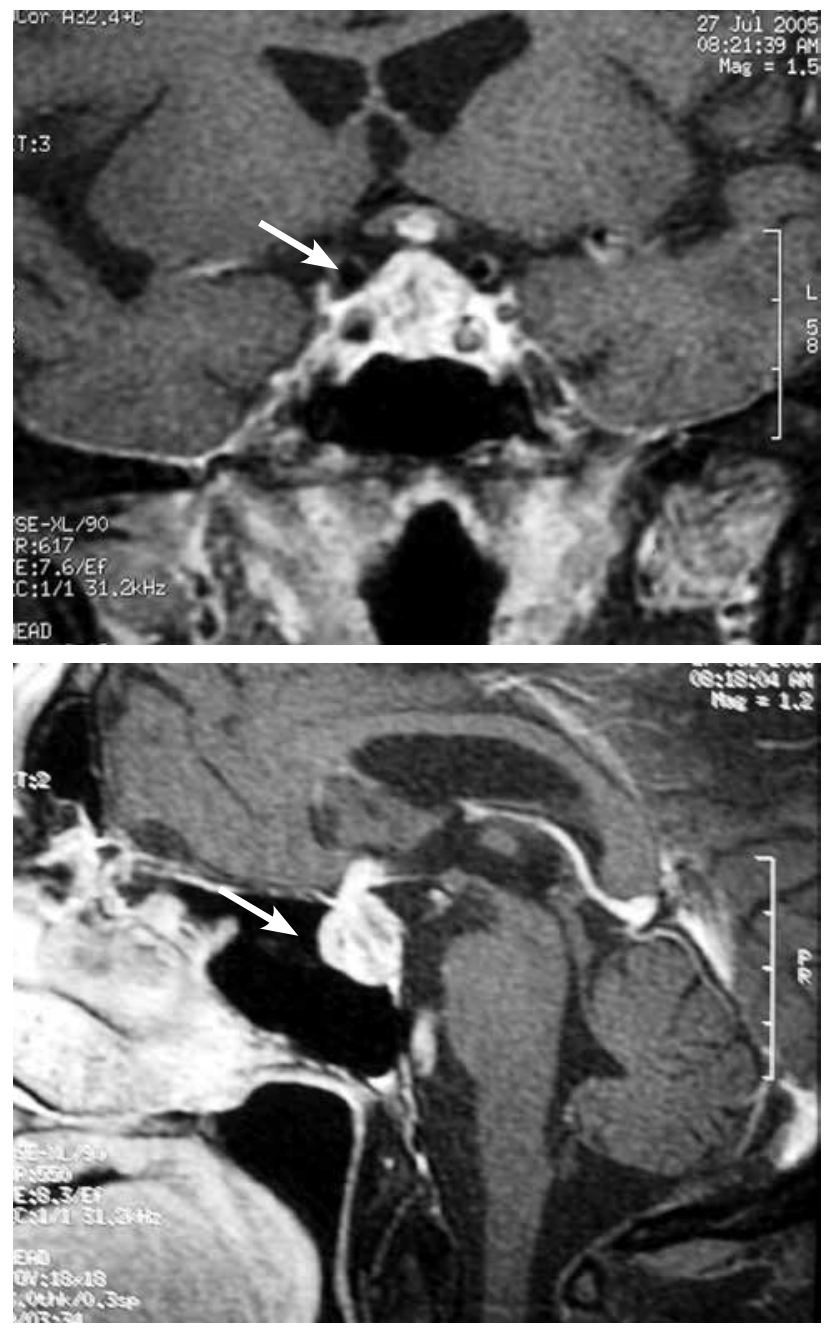

Figure 1. Magnetic resonance imaging demonstrating the compression of the optic chiasm (white arrows) by the pituitary metastasis of renal cell carcinoma, with heterogeneous enhancement after gadolinium infusion.

Virtually any tumor can metastasize to the pituitary gland, but breast and lung cancer are the most prevalent, accounting for two thirds of the cases (4). At presentation, most are widespread tumors with multiple site implantation, and mainly involving elderly patients (5-6). Despite the association with breast cancer there does not seem to be any gender predominance (7).

Secondary spread of renal carcinoma was previously described in $2.6 \%$ of metastatic pituitary lesions in a series of 360 cases (4). In another study of 88 cases of pituitary metastatic lesions there was no case of metastatic spread of renal carcinoma (8).

Most metastatic tumors to the pituitary gland involve the posterior lobe of the gland (3), mainly due to a larger area of contact with the adjacent dura, and to the direct systemic arterial supply of posterior lobe through the hypophyseal arteries. The anterior pituitary is 

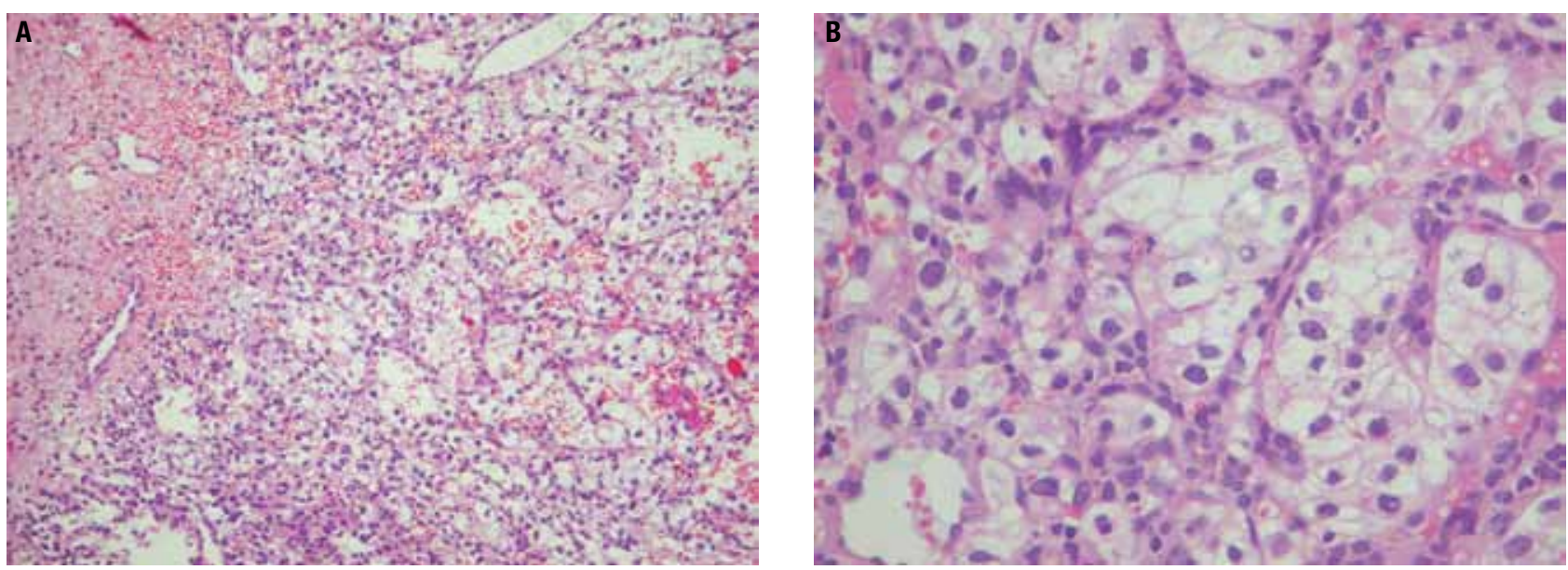

Figure 2. Histological examination of the pituitary tumor: hematoxylin-eosin stain 40x (A) and 100x (B) showing the highly vascular content of renal cell carcinoma.

mainly supplied by the hypophyseal portal system. Therefore, the presence of diabetes insipidus, the rapid progression of symptoms, and the presence of cranial neuropathy favor a diagnosis of metastases over pituitary adenoma. A left abducens nerve palsy was observed in the present case, but there was no evidence of diabetes insipidus. Diabetes insipidus occurred in $45.2 \%$ of the cases in a series of 190 patients with symptomatic pituitary metastases (4) and, in another series of 36 cases, in $61 \%(9)$. On the other hand, a recent series revised 23 cases of pituitary metastases from renal cell carcinoma suggesting that these tumors behave differently from other metastatic malignancies, more commonly involving the anterior pituitary (10). Diabetes insipidus is less common $(30 \%)$ in these cases and hypopituitarism is more frequent, affecting about $90 \%$ of the patients with renal cell carcinoma metastases compared to $23.6 \%$ of the patients with other metastatic tumors (4). Lastly, visual field abnormalities are also more common with renal carcinoma metastases (82\%) (10) than with other primaries $(27.9 \%)$. Accordingly, our patient presented central hypopituitarism with visual field abnormalities without any evidence of diabetes insipidus.

Data on cases of renal cell carcinoma metastatic to the pituitary gland are scarce in the literature and most are case reports (11). In some cases, the diagnosis of the primary neoplasm was performed after the diagnosis of pituitary lesion. In other cases, the primary neoplasm was diagnosed in general 10 years before pituitary metastases, but up to 27 years have evolved in one case (12). MRI is not specific for pituitary metastases, but some characteristics can be seen in sequential images such as a rapidly enlarging sellar and parasellar mass, erosion of sellar floor or posterior clinoid process, thi- ckening of the pituitary stalk, loss of a high-intensity signal from the posterior pituitary (13), isointensity on both T1- and T2-weighted MRI, and cavernous sinus invasion. On tomography, pituitary metastases resemble a primary pituitary neoplasm (2). Despite typical clinical presentation and suggestive imaging most diagnoses are performed only by histopathologic examination as in the present case.

The treatment of pituitary metastasis should be focused on the treatment of the primary lesion, and should only be conducted to alleviate compressive symptoms. The effectiveness of angiogenesis inhibitors has been encouraging (14), suggesting that it is worthy to identify metastatic renal cancer. In this sense a detailed medical history is essential.

This case illustrates that metastatic pituitary lesions can mimic pituitary macroadenoma in typical symptoms and signs. Though the presence of some findings such as rapid growth, cranial neuropathy, and diabetes insipidus favor a diagnosis of metastatic lesion over that of a pituitary adenoma, exceptions can occur depending on the primary malignancy. Therefore, clinicians must keep in mind the possibility of pituitary spread of any neoplasia in patients with a sellar mass.

Disclosure: no potential conflict of interest relevant to this article was reported.

\section{REFERENCES}

1. Gsponer J, DeTribolet N, Deruaz JP, Janzer R, Uske A, Mirimanoff $\mathrm{RO}$, et al. Diagnosis, treatment, and outcome of pituitary tumors and other abnormal intrasellar masses. Retrospective analysis of 353 patients. Medicine (Baltimore). 1999;78(4):236-69.

2. Sioutos P,Yen V, Arbit E. Pituitary gland metastases. Ann Surg Oncol. 1996;3(1):94-9. 
3. McCormick PC, Post KD, Kandji AD, Hays AP. Metastatic carcinoma to the pituitary gland. Br J Neurosurg. 1989;3(1):71-9.

4. Komninos J, Vlassopoulou V, Protopapa D, Korfias S, Kontogeorgos G, Sakas DE, et al. Tumors metastatic to the pituitary gland: case report and literature review. J Clin Endocrinol Metab. 2004;89(2):574-80.

5. Houck WA, Olson KB, Horton J. Clinical features of tumor metastasis to the pituitary. Cancer. 1970;26(3):656-9.

6. Max MB, Deck MD, Rottenberg DA. Pituitary metastasis: incidence in cancer patients and clinical differentiation from pituitary adenoma. Neurology. 1981;31(8):998-1002.

7. Fassett DR, Couldwell WT. Metastases to the pituitary gland. Neurosurg Focus. 2004;16(4):E8.

8. Teears RJ, Silverman EM. Clinicopathologic review of 88 cases of carcinoma metastatic to the pituitary gland. Cancer. 197;36(1):216-20.
9. Morita A, Meyer FB, Laws ER, Jr. Symptomatic pituitary metastases. J Neurosurg. 1998;89(1):69-73.

10. Gopan T, Toms SA, Prayson RA, Suh JH, Hamrahian AH, Weil RJ. Symptomatic pituitary metastases from renal cell carcinoma. $\mathrm{Pi}$ tuitary. 2007;10(3):251-9.

11. Weber J, Gassel AM, Hoch A, Spring A. Concomitant renal cell carcinoma with pituitary adenoma. Acta Neurochir (Wien). 2003;145(3):227-31.

12. Anniko M, Lundquist PG, Silfversward C, Wersall J. Hypernephroma metastasis in the pituitary gland. A case report. Arch Otorhinolaryngol. 1981;232(3):227-32.

13. Chaudhuri R, Twelves $C$, Cox TC, Bingham JB. MRI in diabetes insipidus due to metastatic breast carcinoma. Clin Radiol. 1992;46(3):184-8.

14. Brugarolas J. Renal-cell carcinoma - Molecular pathways and therapies. N Engl J Med. 2007;356(2):185-7. 